The research program of the Center for Economic Studies

(CES) produces a wide range of theoretical and empirical economic analyses that serve to improve the statistical programs of the U.S. Bureau of the Census. Many of these analyses take the form of CES research papers. The papers are intended to make the results of CES research available to economists and other interested parties in order to encourage discussion and obtain suggestions for revision before publication. The papers are unofficial and have not undergone the review accorded official Census Bureau publications. The opinions and conclusions expressed in the papers are those of the authors and do not necessarily represent those of the U.S. Bureau of the Census. Republication in whole or part must be cleared with the authors.

\title{
CAPITAL-ENERGY SUBSTITUTION REVISITED: NEW EVIDENCE FROM MICRO DATA
}

\author{
by \\ Sang V. Nguyen and Mary L. Streitwieser* \\ Center for Economic Studies \\ U. S. Bureau of the Census \\ Washington D. C., 20233
}

CES 97-4 April 1997

All papers are screened to ensure that they do not disclose confidential information. Persons who wish to obtain a copy of the paper, submit comments about the paper, or obtain general information about the series should contact Sang V. Nguyen, Editor, Discussion Papers, Economic Planning and Coordination, Center for Economic Studies, Washington Plaza II, Room 211, Bureau of the Census, Washington, DC 20233-6101, (301-457-1882) or INTERNET address snguyen@info.census.gov. 


\section{ABSTRACT}

We use new micro data for 11,520 plants taken from the Census Bureau's 1991 Manufacturing Energy Consumption Survey (MECS) and 1991 Annual Survey of Manufactures (ASM) to estimate elasticities of substitution between energy and capital. We found that energy and capital are substitutes. We also found that estimates of Allen elasticities of substitution -- which have been used as a standard measure of substitution -- are sensitive to varying data sets and levels of aggregation. In contrast, estimates of Morishima elasticities of substitution -which are theoretically superior to the Allen elasticities -- are more robust (except when two-digit level data are used). The results support the views that (i) the Morishima elasticity is a better measure of factor substitution and (ii) micro data provide more accurate elasticity estimates than those obtained from aggregate data. Our findings appear to resolve the long-standing conflict among the estimates reported in the many previous studies regarding energy-capital substitution/complementarity.

Keywords: Energy-Capital Substitution, Micro Data, Morishima Elasticities of Substitution, and Manufacturing Energy Consumption Survey.

*The authors are grateful to Russell o. Jones and seminar participants at the Center for Economic Studies for their comments. 


\section{I . INTRODUCTION}

Since the 1973 energy crisis, economists and policy analysts have debated about whether energy and capital are substitutes or complements (see e.g., Apostolakis, 1990). The issue has received much attention because of its important policy implications. If capital and energy are substitutes, then an increase in energy prices would lead to an increase in the demand for capital. In this case, energy conservation policies promoting new energy-saving physical capital would be predicted to have the desired effect. However, if they are complements, then rising energy prices would adversely effect capital formation and, hence, such policies would be counterproductive. Yet, after more than two decades, economists have not come to an agreement as to whether energy and capital are complementary or substitutable. The debate has been fueled by a large number of conflicting econometric estimates of the elasticity of substitution between energy and capital. For example, using time-series data Hudson and Jorgenson (1973) and Berndt and Wood (1975) found that energy and capital are complements. In contrast, Humphrey and Moroney (1975), Griffin and Gregory (1976) and Halvorsen (1977) found energy and capital substitutable based on their cross-section estimates. Other studies, such as those by Field and Grebenstein (1980), Hazilla 
and Kopp (1984), Nguyen and Andrews (1989) and Morrison (1993), found mixed results.

Researchers have devoted considerable efforts to reconciling the differences in these results. Griffin and Gregory (1976) and Apostolakis (1990), for example, suggest that cross-section data may capture the long run industry response and result in the estimated substitutable relationship between capital and energy In contrast, time-series data reflect short run responses to price changes and thereby lead to a complementary relationship between the two inputs. But, this explanation is not entirely satisfactory. Chung (1987) used time-series data and found that capital and energy are substitutes, while Field and Grebenstein (1981) used cross-section data and found mixed results. Other explanations for the conflicting results have also been offered. Among other things, these include differences (i) in model specifications (three versus four factor model, e.g., Berndt and Wood, 1979), (ii) in the definition of technical change (Griliches, 1967), (iii) in the definition and measurement of capital (e.g., Field and Grebenstein (1980), Wood and Hirsch, 1981 and Morrison, 1993) and (iv) in the aggregation of energy (e.g., Nguyen and Andrews, 1989). But, the intricacies of the relationships have not been clarified, and therefore the controversy surrounding the issue of capital-energy 
substitutability/complementary has not yet been resolved (see Apostolakis, 1990).

The above findings are viewed with great skepticism by a number of economists. Solow (1987), for example, discounts previous estimated elasticities of substitution, arguing that these estimates are subject to intractable aggregation biases. He points out that aggregate manufacturing outputs consist of many products that have different energy intensities. Thus, when energy prices vary, changes in the composition of aggregate output will take place concurrently with factor substitution that occurs within the production of each product. As a result, it is not possible for researchers to sort out these effects with aggregate data. Solow concludes that:

"[E]stimates of factor substitutability based on aggregate data are misleading because they capture more than simply technological substitution. On this view, none of the various empirical measures of factor substitutability is correct; they are not measuring what they want. Factor substitution is a micro economic phenomenon, and is best examined by looking at microeconomic data." ( J. Solow, 1987, p. 612)

In a similar vein, Miller (1986) points out that, at aggregate levels (e.g., three- or two-digit industry groups which are mixtures of many industries), as energy prices change product mix substitution effects dominate the true factor substitution effects. Consequently, elasticity of substitution estimates based on aggregate cross-section data are most likely to be biased upward, while those based on aggregate time-series data 
are most likely to be biased downward. For cross-section data, product mix differs among states, regions, and countries because of regional comparative advantages: energy prices, for example, are cheaper in some states than others and energy-intensive products are often produced where energy costs are lowest. Thus, cross-section data at high levels of aggregation will

overestimate the degree of technical substitution between energy and other inputs. For time-series data, Miller argues that, among other things, as energy prices rise, prices of products (in particular, energy-capital intensive products) also rise. This will reduce the demand for these products, lower their production and hence the demand for factor inputs including capital and energy. Thus energy price changes cause systematic change in output composition between energy-capital intensive industries and other industries, making it appear that energy and capital are complements in the production process.

Perhaps more fundamentally, other economists have contended that the Allen partial elasticity of substitution (AES) -- which has been used as a standard statistic reported in empirical studies on capital-energy substitution -- does not measure the ease of substitution. Blackorby and Russell (1989) formally showed that the Morishima elasticity of substitution (MES) (Morishima, 1967), rather than the AES, is an exact measure of factor substitution, in terms of adjustment along an isoquant. 
- In spite of its theoretical superiority, the MES has been rarely used for measuring factor substitution. Relatively few published studies used the MES in their empirical work. Ball and Chambers (1982) used both the AES and MES to measure factor substitution in the U.S. meat products industry. They found that energy and capital are Allen complements, but Morishima substitutes. Sickles and Streitwieser (1992) estimated elasticities of substitution among inputs in the U.S. interstate natural gas pipeline industry and found that energy and capital (compressors and pipelines) are both Allen and Morishima substitutes. Nguyen and Reznek (1993) also used both the AES and MES to measure factor substitution in five 4-digit industries. They found that capital and materials (including energy) are substitutes by both measures. Recently, Thompson and Taylor (1995) used the estimates of price elasticities of demand reported in eight previous studies to calculate the corresponding MES estimates. They found the mean of the MES between capital and energy equal to 1.01 with a variance of 0.54 , whereas the mean of the AES equals 0.17 with a variance of 20.60 . They concluded that energy and capital are substitutes. While these studies are useful, their findings are subject to certain limitations. The results of the first three studies are limited to a few individual industries, while Thompson and Taylor's results are simple means of estimates based on data varying 
widely in geography, levels of aggregation, and model specifications. ${ }^{1}$

In this paper, we revisit the issue of energy-capital substitution with more appropriate data and a theoretically correct measure of elasticity of substitution. More specifically, we use micro (plant level) data with a four factor translog production model to estimate Morishima elasticities of substitution among the factor inputs -- with special emphasis on the elasticity between energy and capital. For comparison, we also estimate the corresponding cross-price elasticities of demand, AES, and shadow elasticities. Our model is estimated using a sample of nearly 12,000 U.S. manufacturing establishments taken from the newly available 1991 Manufacturing Energy Consumption Survey (MECS) and the 1991 Annual Survey of Manufacturers (ASM); both surveys are conducted by the U.S. Bureau of the Census.

Our principal finding is that energy and capital are substitutes. Our analysis indicates that the MES, rather than the standard AES, is a correct measure of factor substitution. Moreover, estimates for the AES are sensitive to varying data samples and levels of aggregation. In contrast, MES estimates are more stable across the different data sets -- except when 2-

\footnotetext{
1 The eight studies considered by Thompson and Taylor are: Anderson (1981), Denny, et al. (1981), Griffin and Gregory (1976), Hudson and Jorgenson (1974), Berndt and Wood (1975), Berndt and Khaled (1979), Walton (1981) and Turnovsky, et al. (1982).
} 
digit data are used and estimation problems associated with the small sample become overwhelming. Thus, our results support the views that (i) the MES is a better measure of factor substitution than the AES and (ii) micro data provide more accurate estimates of elasticities of substitution than those obtained from highly aggregated data.

The remainder of the paper is organized as follows. Section I discusses the empirical model and elasticity measurement. Data and estimation methods are described in section III. Section IV reports and discusses the results. Section V contains concluding remarks and a plan for future research. Finally, the Data Appendix describes in more details the data set and variable construction.

\section{MEASURING FACTOR SUBSTITUTION}

A. Production Function Model

Elasticities of substitution among production inputs can be obtained from estimating either a production function or its dual cost function. While previous studies on capital-energy substitution often derived their elasticities of substitution from a cost function, we choose to apply a production function in our analysis. This is because data on input prices -- required 
for the estimation of a cost function -- are not available at the plant level. ${ }^{2}$

We assume that there exists a production function that relates output and input such that

$$
Q=F(X, Z)
$$

where $\mathrm{Q}$ represent output, $\mathrm{X}$ is a vector of inputs, and $\mathrm{Z}$ is a vector of other relevant explanatory variables. If $Q$ is homogeneous of degree $\lambda$, then

$$
F(X, Z) r^{\lambda}=F(r X, Z)
$$

where $\lambda$ is a constant and $r$ is any positive real number. Assuming cost minimization and using the generalized Euler's theorem, we can derive the following cost share equation system:

$$
\begin{aligned}
S_{i} & =f_{i} / \lambda F, \\
& =(1 / \lambda)\left(\partial \ln Q / \partial \ln X_{i}\right),
\end{aligned}
$$

where $\mathrm{f}_{\mathrm{i}}=\partial \mathrm{F} / \partial \mathrm{X}_{\mathrm{i}}$.

For estimation we need a specific functional form for $F$. Because we are interested in factor substitution in production, it is most appropriate to use a functional form that does not impose unnecessary restriction on the substitution relationship

2 There is no a priori reason for preferring the production function over the cost function or vice versa. Empirically, however, Burgess (1975) found that the translog production function specification is superior to the translog cost function in terms of goodness of fit and smaller standard errors of the parameter estimates. 
among the factor inputs. Following previous studies, we specify the following four-factor translog production function

$$
\begin{aligned}
\ln Q= & \alpha_{o}+\sum_{i=1}^{4} \alpha_{i} \ln X_{i}+\frac{1}{2} \sum_{i=1}^{4} \sum_{i=1}^{4} \beta_{i j} \ln X_{i} \ln X_{j}+ \\
& \alpha_{M U} M U+\sum_{k=1}^{140} \alpha_{k} \operatorname{IND}+\sum_{r=1}^{9} \alpha_{r} R E G,
\end{aligned}
$$

where $\mathrm{ln}$ is the natural logarithm, $\mathrm{Q}$ is output, and $\mathrm{X}_{\mathrm{i}}$ are the factor inputs capital, labor, energy, and materials. MU is a dummy variable to identify whether the plant is owned by a single- or multi plant firm. Industry and geographic region are represented by the class dummy variables IND and REG, respectively. Industry dummies are included in the model to account for industry specific effects, including industry specific energy price variations. Geographic region is included to accommodate region specific effects, particularly regional differences in energy prices.

Differentiating equation (4) with respect to each factor input and assuming competitive input markets and cost minimization, we derive the logarithmic marginal productivity conditions, or cost share equations, of the following form:

$$
S_{i}=\frac{1}{\lambda}\left(\alpha_{i}+\sum_{j=1}^{4} \beta_{i j} \ln X_{j}\right),
$$


where $\lambda$ is the degree of homogeneity, or returns to scale, of the production function $F$.

B. Elasticities of Substitution

Conventionally, the Allen partial elasticity of substitution (AES) and the cross-price elasticity of factor demand (CPE) are used to measure the substitution relationships among inputs in production. The AES between input $X_{i}$ and $X_{j}$ is defined $a^{3}$

$$
\sigma_{i j}=\frac{\left|\bar{F}_{i j}\right|}{|\bar{F}|} \frac{\sum_{i=1}^{4} f_{i} X_{i}}{X_{i} X_{j}} \quad \text { for all } i, j,
$$

where $X_{i}$ is the $i^{\text {th }}$ input and $f_{i}$ is the partial derivative of the production function $F$, with respect to $x_{i} \cdot|\bar{F}|$ is the determinant of the bordered Hessian matrix $\bar{F}$ and $\left|\bar{F}_{i j}\right|$ is the cofactor associated with element $f_{i j}$ in $\bar{F}$. Within the context of a four-factor translog production function, the AES from equation (1) can be estimated using the formula

$$
\sigma_{i j}=\lambda \frac{\left|G_{i j}\right|}{|G|}
$$

where $\lambda$ is the returns to scale and $|G|$ is the determinant of the bordered Hessian matrix:

3 See Allen, 1938, p. 504. 


$$
G=\left[\begin{array}{ccccc}
0 & \lambda S_{K} & \lambda S_{L} & \lambda S_{E} & \lambda S_{M} \\
\lambda S_{K} & \left(\beta_{K L}+\lambda^{2} S_{K}^{2}-\lambda S_{K}\right) & \left(\beta_{K L}+\lambda^{2} S_{K} S_{L}\right) & \left(\beta_{K E}+\lambda^{2} S_{K} S_{E}\right) & \left(\beta_{K M}+\lambda^{2} S_{K} S_{M}\right) \\
\lambda S_{L} & \left(\beta_{K L}+\lambda^{2} S_{K} S_{L}\right) & \left(\beta_{L L}+\lambda^{2} S_{L}^{2}-\lambda S_{L}\right) & \left(\beta_{L E}+\lambda 2 S_{L} S_{E}\right) & \left(\beta_{L M}+\lambda 2 S_{L} S_{M}\right) \\
\lambda S_{E} & \left(\beta_{K E}+\lambda 2 S_{K} S_{E}\right) & \left(\beta_{L E}+\lambda^{2} S_{L} S_{E}\right) & \left(\beta_{E E}+\lambda^{2} S_{E}^{2}-\lambda S_{E}\right) & \left(\beta_{E M^{2}}{ }^{2} S_{E} S_{M}\right) \\
\lambda S_{M} & \left(\beta_{K M}+\lambda^{2} S_{K} S_{M}\right) & \left(\beta_{L M}+\lambda^{2} S_{L} S_{M}\right) & \left(\beta_{E M^{+}}+\lambda^{2} S_{E} S_{M}\right) & \left(\beta_{M M^{+}}+\lambda^{2} S_{M}^{2}-\lambda S_{M}\right)
\end{array}\right]
$$

$\left|G_{i j}\right|$ is the cofactor associated with element $g_{i j}$ in $G, S_{i}$ is the actual factor input cost share, $\$_{i j}$ and $\lambda$ are the estimated parameters of the production function (4).

Allen (1938) has shown that the price elasticities of factor demand ( $\mathrm{CPE}$ ) are related to the AES as follows

$$
\eta_{i j}=\frac{\partial X_{i}}{\partial w_{j}} \cdot \frac{w_{j}}{X_{i}}=S_{j} \sigma_{i j}, \quad \quad \text { for all } i, j,
$$

where $\eta_{i i}$ and $\eta_{i j}$ are the own and cross-price factor demand elasticities, and $w_{i}$ and $S_{i}$ are the $i^{\text {th }}$ factor's input price and cost share.

Before proceeding, some important properties of the above elasticities should be noted. First, both the AES and CPE are one-price-one-factor (OPOF) elasticities. That is, both elasticities measure the responsiveness of input $i$ to a one percent change in the price of input $j$, all other prices and output held constant. Second, the cross AESs are symmetric (i.e., $\sigma_{i j}=\sigma_{j j}$ ), but the CPEs are generally not symmetric (i.e., $\dot{\eta}_{i j}$ $\left.\neq \dot{\eta}_{j i}\right)$. Lastly, both the AES and CPE must have the same sign. A positive value of $\sigma_{i j}$ or $\dot{\eta}_{i j}$ indicates that an increase in the 
price of input $j$ will lead to an increase in the demand for input $i$, indicating that the inputs are substitutes. Conversely, a negative value of the elasticities indicates the two inputs are complements.

Thus, it is clear that the AES is inferior to the CPE because the AES is more restrictive, due to the symmetry property, and it is less informative. Indeed, from (9) it is clear that the AES is simply a disguised CPE obtained by dividing the CPE by a cost share. Therefore, it does not have a clear interpretation. In spite of its shortcomings, the AES has been used as a standard statistic reported in empirical studies of factor substitution in production (e.g., see Berndt and Wood, 1975, Magnus 1979, and Turnovsky and Donnelly, 1984). Recently, researchers have begun to highlight the weaknesses of the AES. In particular, Blackorby and Russell (1989) show that the AES is uninformative: it does not measure the ease of substitution and provides no new information about factor shares. More important, they show that an alternative, the Morishima elasticity of substitution (MES), is an appropriate measure of factor substitution (or complementarity) because it is an exact measure of the curvature of the isoquant (or the ease of substitution). Thompson and Taylor (1995) argue that the MES is the preferred elasticity to measure the capital-energy substitutability for two reasons. First, the energy cost share is small relative to the 
other input cost shares and "... relatively small variations in energy utilization will induce sizable variations in estimates of the Allen elasticity of substitution." Second, they argue that from a policy perspective, an elasticity which measures the response of the capital/energy ratio, rather than the change in capital, to price is more relevant.

Blackorby and Russell (1989) show that the MES can be defined as

$$
\sigma_{i j}^{m}=\eta_{i j}-\eta_{j j}, \quad \text { for all } i, j ; i \neq j .
$$

Substituting (9) into (10), we can define the MES in terms of the AES, as

$$
\sigma_{i j}^{m}=S_{j}\left(\sigma_{i j}-\sigma_{j j}\right), \quad \text { for all } i, j ; i \neq j .
$$

Unlike the AES which is symmetric, the MES is not necessarily symmetric, in absolute value, or in sign. Consequently, in the case of more than two inputs, the classification of one input as a complement or substitute for another input will depend on which input price changes. From (11) it can be seen that because the own AES elasticity $\left(\sigma_{j j}\right)$ is always negative, two inputs which are AES substitutes are also Morishima substitutes. However, the converse does not hold. A pair of Morishima substitutes may be complements by the AES measure. 
Note that the MES $\left(\sigma_{i j}^{m}\right)$ is a one-price-two-factor (OPTF)

elasticity, measuring the percentage change in the ratio of input $j$ to input $i$ when the price of input $i$ changes one percent. Chambers (1988) shows that the MES can be modified to measure the technical substitution between two inputs in response to changes in their relative prices. He derives the following shadow elasticity of substitution (SES):

$$
\sigma_{i j}^{s}=\frac{S_{i}}{S_{i}+S_{j}} \sigma_{i j}^{m}+\frac{S_{j}}{S_{i}+S_{j}} \sigma_{i j}^{m}
$$

where $S_{i}$ and $S_{j}$ are cost shares of input $i$ and input $j$. Thus, the two-price-two-factor $\sigma^{\text {s }}$ is a weighted average of two MESs where the weights are given by the relative cost shares of the two inputs under consideration. An advantage of this elasticity over the un-weighted MES, $\sigma^{m}$, is that it is symmetric and measures the technical substitution between the two inputs to changes in their relative prices.

\section{DATA AND ESTIMATION PROCEDURES}

\section{A. Data}

We utilized a new micro database recently available: the 1991 Manufacturing Energy Consumption Survey (MECS) conducted by the U.S. Bureau of the Census. We use these cross-section data simply because plant level time-series data are not available. 
The 1991 MECS is a unique data set which provides, for the first time, an excellent opportunity for examining energy-capital substitution at the production unit (plant) level. While crosssection data are subject to some limitations, they have certain advantages for the purpose of this study. In particular, crosssection data reflect technology and market conditions at a single time period and thereby allow us to avoid the problem of separating the effects of factor substitution from those of technological change and changes in market conditions on production. The data also eliminate other effects that timeseries data may capture such as dynamic adjustment due to changes in relative prices and external shocks. Finally, our crosssection data set, containing a large number of observations, allows us avoid the problems and biases associated with small samples used in most previous studies.

The 1991 MECS is a plant level survey of over 14,000 manufacturing plants, collecting information on quantities and expenditures of energy consumed in production for 37 energy sources. The data on energy are exactly what we need for estimating production function that includes energy as a factor of production (see Solow, 1987). Although the MECS surveys less than 10 percent of the manufacturing establishment universe, the sample accounts for approximately 35 percent of total employment and 55 percent of shipments of the manufacturing universe. On a 
weighted basis, the survey covers 80 percent of total employment and 90 percent of shipments of the U.S. manufacturing sector.

The 1991 MECS was designed to generate estimates on energy consumption for all the 20 two-digit major groups in manufacturing and 42 three- and four-digit industry groups which meet one of the following criteria: i) energy-intensive production; or ii) high-growth industries such as computers and medical instruments; or iii) industries with identifiable policy interest or conservation opportunities, as listed in Table Al of the Appendix. Thus the SIC category is the single most important classification variable in the MECS data. The probability of selection is proportional to an energy measure of size. Therefore large plants have a greater probability of being in the sample than small plants.

While the MECS provides excellent data for energy analysis, it does not collect data on outputs and non-energy inputs such as capital, labor and materials that are required for estimating a production function. Fortunately, data on outputs and non-energy inputs and related variables at the plant level can be obtained from the 1991 Annual Survey of Manufacturers (ASM). Among other things, the ASM contains data on total value of shipments, inventories, book value of capital assets (buildings and structures, and machinery), employment (numbers of production workers, non-production workers and production worker hours), 
total salaries and wages, and expenditures for parts, materials and contract work. These data allow us to construct data on outputs, capital, labor, and material inputs. Data on energy input are taken directly from the MECS.

Both the MECS and the ASM contain common plant and firm identification numbers which facilitate plant level matching of the MECS and the ASM data. After matching the two data sets and omitting plants with missing data or non-positive output and input values, we have 11,520 plant observations in our final data set. (For a more complete data description, see the Data Appendix) .

Sample means for the data used in estimation are reported in Table 1. The first three columns show the variable means from the full sample. Weighted and unweighted statistics (columns 1 \& 2) differ because of the sample design. The un-weighted mean values in column (2) illustrate the sample selection bias toward larger, energy intensive plants relative to the manufacturing universe, as represented by the weighted means in column (1). Column(3) shows variable means for two-digit industry group aggregates based on the full sample.

Column (4) differs from column (1) in that the latter reports the means based on only 3,637 plants sampled from the 40 selected energy-intensive four-digit industries, whereas the former shows the means based on the full working sample. Column 
(5) reports the means from the aggregation of these 40 industries to the four-digit level. The three-digit data in column (5) are derived by aggregating the 40 industries to the three-digit level.

B. Estimation Procedures and Hypothesis Tests

The translog production function (4) is assumed to be symmetric and homogeneous of degree $\lambda$. Therefore, the following standard restrictions are imposed in the estimation:

$$
\sum_{i=1}^{4} \alpha_{i}=\lambda, \quad \sum_{i=1}^{4} \beta_{i j}=0, \quad \sum_{j=1}^{4} \beta_{i j}=0, \text { and } \sum_{i=1}^{4} \sum_{j=1}^{4} \beta_{i j}=0,
$$

Monotonicity and convexity are not imposed, but will be tested for after estimation. We append a random disturbance term $u_{i}$ to the production function and to each share equation, $i=K, L, E$, $M$, and assume the resulting disturbance vector $u=\left\{u k, u_{L}, u_{E}\right.$, $\left.u_{m}\right\}$ is multivariate normally distributed with mean vector zero and constant covariance matrix.

Since the cost shares sum to one, the disturbance covariance matrix of the share equation system (5) is singular. Therefore, the material cost share equation is dropped from the estimation. The resulting estimates are invariant to the equation dropped if a maximum likelihood estimation procedure is used. We use the full information maximum likelihood method (FIML) to jointly 
estimate the production equation (4) and three of the four cost share equations (5) $\cdot^{4}$

Our primary focus in this paper is on elasticities of substitution; however, because these elasticities are derived from the parameter estimates of the model, it is informative to test whether or not the production function employed here adequately describes U.S. manufacturing production technology . For the purposes of this study, we restrict ourselves to the following three hypothesis:

(i) The translog function, rather than the Cobb-Douglas function is an adequate description of U. S. manufacturing production technology.

(ii) The material input is weakly separable from other inputs and may be omitted from the production function.

(iii) The U.S. manufacturing production function is homogeneous of degree 1 (i.e., $\lambda=1$ ).

Hypothesis (i) imposes global separability which implies that the AES between any two inputs in the production equals one. This is equivalent to testing whether all the second-order terms of the translog function are equal to zero (i.e., $\beta_{\mathrm{ij}}=0$ for all $i$ and $j$ ). If this restriction is satisfied then the translog production function reduces to a logarithmic Cobb-Douglas production

4 Diewert (1974) suggests that one should include the translog production function (or cost function) with the cost share equations for efficient estimation. 
function. Hypothesis (ii) is equivalent to requiring $\sigma_{\mathrm{KM}}=\sigma_{\mathrm{LM}}=\sigma_{\mathrm{EM}}$ =1. If this condition is satisfied then the value-added KLE production model such as the one in Griffin and Gregory (1976) should not be reject as a proper specification. In view of the debate about the gross-output KLEM model versus the value-added KLE model (e.g., see, Berndt and Wood, 1981 and Griffin, 1981), this test is important. Finally, hypothesis (iii) states the production function is characterized by constant returns to scale (CRTS). That is, $\lambda=1$. This hypothesis test is important because most previous studies of energy-capital substitution were based on the assumption of CRTS.

The above hypotheses can be tested based on the values of the L-statistics which are equal to two times the difference of the logs of the likelihood functions of the restricted and unrestricted models. The L-statistic is asymptotically distributed as a $\chi^{2}$ variable with degree of freedom equal to the number of restrictions.

To test whether or not the model parameter estimates, and hence the estimated elasticities of substitution, are sensitive to levels of data aggregation, we estimate the model (and the associated elasticities) using plant level data and data aggregated at four-, three-, and two-digit SIC levels and compare the results. If aggregation biases exist, we would expect that estimates of elasticities of substitution between capital and 
energy based on data aggregated at higher levels of aggregation would be larger than those based on data aggregated at lower levels of aggregation (see Miller, 1986).

Our model estimation is based on weighted data, using the MECS sample weights, with one exception. We also estimate the model with the unweighted, full sample to illustrate the bias in the sample design.

\section{EMPIRICAL RESULTS}

A. The Estimated Production Functions:

Before examining the estimates, it is informative to know whether or not the underlying production function is "wellbehaved". A well-behaved production function requires that output increases monotonically with all inputs and its isoquants are strictly quasi-concave. Monotonicity implies that all the estimated cost shares of inputs are non-negative. The concavity condition is satisfied if the bordered Hessian of first and second partial derivatives is negative semidefinite. Our base model (weighted plant-level sample) meets the regularity conditions fairly well. In terms of monotonicity, estimated capital, labor, energy, and material factor shares are positive for 99.6, 97.4, 95.9, and 98.9 percent of the observations, respectively. Concavity conditions are met for all but 372 (3.2 
percent) of the 11,520 observations. Except for the production function estimated using two-digit data, for all other estimated productions, there are no statistically significant violations of these conditions when evaluated at the means. ${ }^{5}$ When using twodigit data, the concavity is violated even it is evaluated at the means of the variables.

We report the parameter estimates (and the associated standard errors) from the model in Table A2 to illustrate their statistical significance, although the individual estimates have little intuitive value because of the complexity of the translog form. In the Table, columns (1) - (3) present the estimates based on the full sample (weighted, unweighted and two-digit aggregate), while columns (4) - (6) show the estimates based on the 40 industry subsample (weighted, four- and three-digit aggregates). ${ }^{6}$ From the Table, it is clear that the estimates based on micro data are much more precise than those based on aggregate data in view of smaller standard errors. Except for the estimate for $\beta_{\mathrm{LE}}$ in column (3), all the estimates based on micro data are highly significant, while those based on aggregate

5 While we find no statistically significant violation of regularity conditions when evaluated at the means of the variables, these conditions are not satisfied at a number of data points (less than 5 percent of the observations). However, Wales (1977) noted that the rejection of either the monotonicity or the concavity condition does not necessarily imply that the elasticity estimates are incorrect.

6 When aggregating the 40 industry subsample to the two-digit level, there are too few observations to estimate the production model. 
data are far less significant. In particular, the estimates for $\dot{\alpha}_{\mathrm{E}}, \beta_{\mathrm{KL}}, \beta_{\mathrm{KE}}$, and $\beta_{\mathrm{LE}}$ are insignificant when using data aggregate at all three levels of aggregation. This suggests that the elasticities estimated using micro data are much more robust and hence more reliable than those obtained from aggregate data.

B. Test Results:

Table 2 reports the results of the L-statistics and $\chi^{2}$ tests for the three hypothesis tests discussed above. The results strongly reject the Cobb-Douglas form in favor of the translog production function as an appropriate description of U.S. manufacturing production technology. The hypothesis that material inputs are separable is also strongly rejected. This result implies that the value-added KLE model is not statistically accepted as the appropriate production model. The KLEM model is a more appropriate one and hence the elasticities of substitution derived from them are more accurate. Finally, even though our estimated returns to scale is very nearly unity (1.004), we statistically reject the hypothesis of constant returns to scale; although, the assumption of constant returns to scale does not impact the resulting elasticities significantly.

C. Factor Substitution

Because our main interest is in the substitution relationship between capital and energy, we report only the estimated elasticities associated with these two inputs in Table 
3. ( A complete set of elasticity estimates are reported in Table A3 of the Appendix.) The Table shows estimates of four types of elasticities associated with energy and capital: price

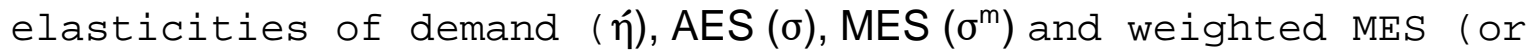
shadow elasticity, $\left.\sigma^{s}\right)$. All these elasticity estimates are evaluated at the sample mean. We use actual cost shares, rather than estimated shares to evaluate the AES and shadow elasticities. ${ }^{7}$ Columns (1) - (3) of the Table report the estimated elasticities based on the full sample (weighted, unweighted, and two-digit aggregates), while columns (4) - (6) show estimates based on the 40 industry subsample (weighted, four- and three-digit aggregates).

The estimated elasticities in column (1) are evaluated based on the model parameters estimated using the full sample in which individual plants are weighted by their MECS sample weight. These results suggest that both energy and capital are responsive to changes in their own prices -- the own price elasticities of energy and capital ( $\dot{\eta}_{\mathrm{EE}}$ and $\left.\dot{\eta}_{\mathrm{KK}}\right)$ are -3.57 and -1.11 . That is, ceteris paribus, a one percent increase in energy prices leads to a 3.57 percent decline in energy demand, whereas a one percent

\footnotetext{
7 Most previous studies evaluated elasticities of substitution at the means of fitted shares. However, Anderson and Thursby (1986) showed it is more appropriate to use actual shares. In particular, they found that "a normal distribution for the AES (Allen elasticity of substitution) is appropriate if the estimator uses the means of the actual factor shares." (p. 652)
} 
increase in the price of capital causes a 1.11 percent decrease in the demand for capital input. The cross-price elasticity estimates $\left(\eta_{\mathrm{ij}}\right)$ show a weak substitution relationship between energy and capital: a one percent increase in energy prices leads to a 0.02 percent increase in capital demand, while a one percent increase in the price of capital results in a 0.21 percent increase in the demand for energy. With these results one can conclude that energy demand is more elastic than the demand for capital and that capital and energy are weak substitutes. The results on the AES suggest the same conclusion, but as already mentioned above, the AES estimates do not provide any new information beyond what the cross-price elasticity of demand reveals about the substitution relationship between energy and capital. In fact, both of these elasticities are limited because they only measure how one input adjusts in response to a change in an input price.

In contrast, the MES gives information on relative input adjustments to changes in an input price. Its estimates in column (1) reveal a much stronger substitution relationship between energy and capital: other things being equal, a one percent increase in energy prices leads to a 3.59 percent increase in the capital energy ratio. However, this relationship is not symmetric: a one percent increase in the price of capital causes only a 1.31 percent increase in the energy capital ratio. 
This asymmetry is due to the fact that the MES measures the responsiveness of input ratios to changes in different input prices. Finally, the weighted MES (shadow elasticity) shows the percentage adjustment in input ratios to changes in factor price ratios. The estimate for the shadow elasticity of substitution between energy and capital indicates that a one percent increase in the energy/capital price ratio (where both prices are allowed to change) lead to a 3.43 percent increase in the energy-capital ratio. Thus, based on the concept of Morishima elasticity, we conclude that energy and capital are strong substitutes. Comparing the above results with those based on the unweighted sample reported in column (2), we find that the unweighted sample underestimates elasticities. In particular, the energy own price elasticity of demand and AES estimates are substantially smaller than those in column (1). Moreover, the unweighted estimates for cross-price elasticities and AESs become negative, though larger in magnitudes. This downward bias in the unweighted elasticities is due to the fact that the MECS is designed in such a way that the unweighted sample is biased toward larger and more energy-intensive relative to the manufacturing universe. These results are not surprising in view that energy-intensive plants are not as (energy) price responsive as other less energy-intensive plants. All estimates for the MES and shadow elasticities between energy and capital are positive 
and are smaller in magnitude relative to those based on the weighted sample. Again, these estimates suggest that energy and capital are substitutes.

When we aggregate the sample to the two-digit level data, column (3), we find that elasticity estimates become erratic: the energy own elasticity estimates $\left(\dot{\eta}_{\mathrm{EE}}\right.$ and $\left.\sigma_{\mathrm{EE}}\right)$ have the wrong sign. These results appear to supports Solow's assertion that elasticity estimates based on aggregate data are unreliable and often misleading. In fairness, we note that the erratic estimates obtained from two-digit data are in part due to the small sample size. ${ }^{8}$

Column (4) reports elasticity estimates based on a weighted sample of 3,637 plants sampled from 40 selected energy-intensive four-digit industries. These estimates are quite similar to those of the unweighted full sample, and are equal or smaller in magnitude. However, their magnitudes are consistently smaller than those obtained from the weighted full sample. Again, this reflects the composition of the subsample: drawn from energyintensive production industries.

We now turn our discussion to the results based on aggregate data from the subsample. Examining the estimates in columns (5) and (6), two important findings emerge with clarity. First,

8 We have only 20 observations in the sample of two-digit data. We note that this small sample size is not unique. Turnovsky and Donnelly (1984), for example, also used a sample of 20 observations for the Australian iron and steel industry. 
energy and capital are substitutes by any measure at the aggregate level, but are complements according to the cross price demand and AES elasticities from the plant level data in column (4). Second, aggregated data generally yields higher estimates of elasticities of substitution than the micro data do. This finding supports the contention that aggregate cross-section data yield upward biases in the estimates of the substitution between energy and capital (Miller, 1986). This bias appears to be more severe in the estimates for the cross-price elasticity of factor demand and the AES than in the MES and shadow elasticities.

Finally, we note that, relative to the Morishima elasticities, the restricted cross-price elasticity of demand consistently underestimates the degree of substitution between capital and energy regardless of levels of aggregation. For example, with plant level data from the full sample (column 1), the value of $\dot{\eta}_{\mathrm{KE}}$ is 0.02 , while that of $\sigma_{\mathrm{KE}}^{\mathrm{m}}$ and $\sigma_{\mathrm{KE}}^{\mathrm{s}}$ are 3.59 and 3.43, respectively. Similar differences occur for all other models.

D. DISCUSSION

Our empirical results can be summarized into the following findings. First, we find that the translog, rather than the Cobb-Douglas production function, is the proper description of U.S. manufacturing production technology. Second, the assumption 
that the material input is separable from other inputs is strongly rejected. Third, the assumption of constant returns to scale is rejected. Fourth, among the four factor inputs, energy is the most price-responsive, while capital is the least priceresponsive. Fifth, energy and capital are weak Allen substitutes for the manufacturing sector as a whole (but may be weak complements for energy intensive plants), but they are strong Morishima substitutes. Finally, data aggregated at higher levels introduce larger biases in the estimates of factor substitution elasticities.

The first finding is not surprising and is consistent with previous evidence that the translog functional form is superior to Cobb-Douglas form in describing production technologies. This is particularly true when one uses a production (or cost) function to study factor substitution because the Cobb-Douglas function imposes strong restrictions on the substitution relationships among factor inputs. Indeed, all studies that focus on testing for these restrictions have unanimously rejected the Cobb-Douglas functional form in favor of more flexible functions, such as the translog. For example, Berndt and Wood (1975), using times-series U.S. manufacturing data, Norsworthy and Malmquist (1983), using time-series U.S. and Japanese manufacturing data, and Turnovsky and Donnelly (1984), using cross-section Australian iron and steel data, strongly reject the 
validity of the Cobb-Douglas functional form. Using U.S. manufacturing plant level data, Nguyen and Reznek (1993) also strongly rejected the Cobb-Douglas specification.

An important implication of the second finding is that the value-added (KLE) model, such as the one used by Griffin and Gregory (1976), is not proper for studying factor substitution. This finding is important because it is a major issue in the capital-energy substitution/ complementarity debate (e.g., see Berndt and Wood, 1981 and Griffin, 1981). More specifically, Hudson and Jorgenson (1974), Berndt and Wood (1975), and Berndt and Khaled (1979), employed the translog KLEM model to estimate the AESs among factor inputs in U.S. manufacturing. They found $\sigma_{\mathrm{KE}}$ negative, having values ranging from -1.39 to -3.32 and concluded that energy and capital are complements. In contrast, Griffin and Gregory (1976) used international pool crosssectional data to estimate a value-added KLE model. They found $\sigma_{\mathrm{KE}}$ positive with values from 1.02 (Belgium) to 1.07 (U.S.) and concluded that capital and energy are substitutes. This led to the subsequent debate.

In an attempt to reconcile these controversial results, Griffin (1981) argues that studies using time-series data, such as that by Berndt and Wood (1975), capture short run factor substitution relationships, while cross-sectional studies capture long run relationships. While this view is supported by 
estimates of some dynamic models such as the work by Pindyck and Rotenberg (1983), other studies such as those by Stapleton (1981), Morrison and Berndt (1981), and Kulatilaka (1985) found that capital-energy complementarity becomes stronger in the long run.

Berndt and Wood $(1979,1981)$ assert that the condition of weak separability of the material input from other inputs imposed by the value-added KLE model is strongly rejected and therefore the KLE specification is not suitable for studying factor substitution. Further, Berndt and Wood show that even if the KLE model is valid, it essentially estimates "gross elasticities", while the KLEM model estimates "net elasticities" and that "gross" and "net" elasticities of substitution can have opposite signs. Thus, the fact that capital and energy are "gross" substitutes, but "net" complements is not theoretically inconsistent. Our findings that material input is not separable from other inputs and that capital and energy are Allen (weak) complements appears to support Berndt and Wood's view. On the other hand, our results do not support Griffin's long run versus short run argument because our cross-section data do not always show (Allen) substitution relationship between capital and energy. There is a composition effect: when the cross-section micro data are dominated by energy intensive plants, we find capital and energy can be complements. 
Our finding that energy is the most price-responsive among the four inputs, while capital is the least price-responsive is expected and is consistent with previous studies. ${ }^{9}$ An important policy implication of this finding is that imposing a tax on energy would be an effective policy to conserve energy.

Our last two findings are directly relevant to the capitalenergy substitution/ complementarity debate: our robust estimates based on a large sample of 11,520 manufacturing plants show that capital and energy are substitutes. We also find aggregate data and sample selection biases in elasticity estimates. These biases are more severe in the estimates for the cross-price elasticity of demand and the partial AES than in those for the MES. For example, our estimates for $\sigma_{\mathrm{KE}}$ range from -1.15 (column 2) to 3.76 (column 5), while those for $\sigma_{\mathrm{KE}}^{\mathrm{s}}$ having values from 2.09 (column 4) to 3.43 (column 1). These result are in agreement with the finding by Thompson and Taylor (1995) that estimates for the AES between capital and energy reported in the literature scattered around zero with values ranging from -22.40 to 18.60. In contrast, using the reported estimates of price elasticities of demand, to calculate values for MES, they found the mean values for $\sigma_{\mathrm{KE}}^{\mathrm{m}}$ and $\sigma_{\mathrm{EK}}^{\mathrm{m}}$ are 1.01 and 0.76 , which are qualitatively consistent with our estimates of 3.59 and 1.31 . Thus, our results, together with Thompson and Taylor's survey,

\footnotetext{
${ }^{9}$ See Thompson and Taylor (1995) for a survey of previous results.
} 
show that the controversy surrounding the issue of capital-energy substitution/complementarity is a result of previous studies that use a wrong measure of elasticity of substitution: the partial AES does not measure the ease of factor substitution and its estimates are highly sensitive to varying data sets.

\section{SUMMARY AND CONCLUSIONS}

In this paper, we revisit the empirical issue of capitalenergy substitutability-complementarity. Our approach differs from earlier studies in that we use micro data (rather than aggregate data) to estimate the theoretically correct Morishima elasticity of substitution (rather than the partial Allen elasticity). Plant-level data are unquestionably more appropriate for measuring technical substitution relationships among factors of production, while the Morishima elasticity of substitution has been proven as an exact measure of factor substitution in terms of adjustments of inputs along an isoquant in response to factor price changes.

Our principal finding is that capital and energy are substitutes in U.S. manufacturing production. We also find that micro data provide more accurate elasticity estimates than those obtained from aggregate data. Our results appear to resolve the long standing conflict among the estimates reported in previous 
studies regarding the substitution relationship between capital and energy.

In concluding, we note that our results are based on crosssection data for a single year. It is important to examine the robustness of these results by using time-series micro data. In particular, the data used should include the years in which there were substantial energy price increases such as those in 1973 and 1979 . 


\section{REFERENCES}

Allen, R.D.G. (1938), Mathematical Analysis For Economists, London; MacMillan.

Anderson, R.G. (1981), "On the Specification of Conditional Factor Demand Function in Recent Studies of U.S. Manufacturing," Modeling and Measuring Natural Resource Substitution, E.R. Berndt and B.C. Field, eds., Cambridge: MIT Press:119-144.

Anderson, R.G. and J.G. Thursby (1986), "Confidence Intervals for Elasticity Estimators in Translog Models," Review of Economics and Statistics, 3:647-656.

Apostolakis, B.E. (1990), "Energy-Capital Substitutability/Complementarity: The Dichotomy," Energy Economics, 1:48-58.

Ball, V.E. and R. Chambers (1982), "An Economic Analysis of Technology in the Meat Product Industry," American Journal of Agricultural Analysis, 64:699-709.

Berndt, E.R. and M.S. Khaled (1979), "Parametric Productivity Measurement and Choice Among Flexible Factional Forms," Journal of Political Economy, 6:1220-1245.

Berndt, E.R., and D.O. Wood (1975), "Technology, Process, and the Derived Demand for Energy," The Review of Economics and Statistics, 68:647-656.

Berndt, E.R., and D.O. Wood (1979), "Engineering and Econometric Interpretation of Energy-Capital Complementarity," American Economic Review, 3:342-354.

Berndt, E. R. and D.O. Wood (1981), "Engineering and Economic Interpretations of Energy-

Capital Complementarity: Reply and Further Results," American Economic Review, $5: 1105-1110$.

Blackorby, C. and R.R. Russell (1989). "Will the Real Elasticity of Substitution Please Stand Up? (A Comparison of the Allen/Uzawa and Morishima Elasticities)," American Economic Review, 4: 882-888. 
Burgess D.F. (1975), "Duality Theory and Pitfalls in the Specification of Technologies," Journal of Econometrics, $3: 105-121$.

Chambers, R.G. (1988), Applied Production Analysis: A Dual Approach, Cambridge, Mass.: Cambridge Press.

Chung, J.W. (1987), "On the Estimation of Factor Substitution in the Translog Model," Review of Economics and Statistics, 69, $2: 409-417$.

Denny, M. , M. Fuss, and L. Waverman, "Substitution Possibilities for Energy: Evidence from U.S. and Canadian Manufacturing," Modeling and Measuring Natural Resource Substitution, E.R. Berndt and B.C. Field, eds, Cambridge, MA: MIT Press:230257 .

Diewert, W.E. (1974), "Application of Duality Theory," Frontiers of Quantitative Economicics, Vol. II, M. Intriligator and D.A. Kendrick, eds, Amsterdam: North-Holland:106-206.

Doms, M. E. (1996), "Estimating Capital Efficiency Schedules Within Production Functions," Economic Inquiry, Vol. 34:7892 .

Dwyer, Douglas W. (1997), "Productivity Races II: The Issue of Capital Measurement," CES Working Paper 97-3.

Field, B.C. and C. Grebenstein (1980), "Capital-Energy

Substitution in U.S. Manufacturing,"

Review of Economics and Statistics, 2:207-212.

Griffin, J.M. (1981), "Engineering and Econometric

Interpretations of Energy-Capital

$5: 1100-1104$.

Complementarity: Comment," American Economic Review,

Griffin, J.M. and P.R. Gregory (1976), "An Intercountry Translog Model of Energy Substitution Responses," American Economic Review, 66:845-857.

Griliches, Z. (1967), "Production Functions in Manufacturing: Some Preliminary Results," The Theory and Empirical Analysis of Production, M. Brown, ed., New York.

Halvorsen, R. (1977), "Energy Substitution in U.S. Manufacturing," Review of Economics and Statistics, 59:381388 . 
Hazillia, M. And R. Kopp (1984). Industrial Energy Substitution: Econometric Analysis of U.S. Data, 1958-1974, EA-3462, Final Report, Palo Alto, Ca: Electric Power Research Institute.

Hudson, E.A. and D.W. Jorgenson (1973), "U.S. Energy Policy and Economic Growth, 19752000," Bell Journal of Economics, 5:461-514.

Humphrey, D.B.and J.R.. Moroney (1975), "Substitution Among Capital, Labor and natural Resources Products in American Manufacturing," Journal of Political Economy, 83:57-82.

Kulatilaka, N. (1985), "Tests on the Validity of Static Equilibrium Models," Journal of Econometrics, 28:253-268.

Magnus, J.R. (1979), "Substitution Between Energy and Non-Energy in the Netherlands 1950-1976," International Economic Review, 20:465-484.

Miller, E. (1986), "Cross-Sectional and Time-Series Biases in Factor Demand Studies: Explaining Energy-Capital Complementarity," Southern Economic Journal, 52, 3:745-762.

Morishima, M. (1967), "A Few Suggestions on the Theory of Elasticity," Keizai Hyoron (Economic Review), 16:145-150.

Morrison, C. (1993), "Energy and Capital: Further Exploration of E-K Interactions and Economic Performance," The Energy Journal, 1:217-243.

Morrison, C. And E. Berndt (1981), "Short-run Labor Productivity in a Dynamic Model," Journal of Econometrics, 16:339-365.

Nguyen, S.V. and S. H. Andrews (1989), "The Effect of Energy Aggregation on Energy Elasticities: Some Evidence from U.S. Manufacturing Data," The Energy Journal, 1:149-156.

Nguyen, S.V. and A. Reznek (1993), "Factor Substitution in Small and Large U.S. Manufacturing Establishments," Small Business Economics, 5:37-54.

Norsworthy, J.R. and Malmquist, D.H. (1983), "Input Measurement and Productivity Growth in Japanese and U.S. Manufacturing," American Economic Review, 73:947-967.

Pindyck, R.S. and J.J. Rotemberg (1983), "Dynamic factor Demands and the Effects of Energy Shocks," American Economic Review, $5: 1066-1079$. 
Sickles, R.C. and M. L. Streitwieser (1992), "Technical Efficiency and Productive Decline in the U.S. Interstate Natural Gas Pipeline Industry under the Natural Gas Act," Journal of Productivity Analysis, 3,1/2 :115-133.

Solow, J.L. (1987), "The Capital-Energy Complementarity Debate Revisited," American Economic Review 77:605-614.

Stapleton, D.C. (1981), "Infering Long-Term Substitution Possibilities from Cross-Section and Time-Series Data," Modeling and Measuring Natural Resource Substitution, E.R. Berndt and B.C. Field, eds, Cambridge: MIT Press:93-118.

Thompson P. and T.G. Taylor (1995), "The Capital-Energy Substitutability Debate: A New Look," The Review of Economics and Statistics, :565-569.

Turnovsky, M. M. Folie, and A. Ulph (1982), "Factor Substitutability in Australian Manufacturing with Emphasis on Energy Inputs," Economic Record, 58, 160:61-72.

Turnovsky M. H.L. and W.A. Donnelly (1984), "Energy Substitution, Separability, and Technical Progress in the Australian Iron and Steel Industry," Journal of Business and Economic Statistics, 1:54-63.

Wales, T.J. (1977), "On the Flexibility of Flexible Functional Forms," Journal of Econometrics, 5:183-193.

Walton, A.L. (1981), "Variations in the Substitutability of Energy and Nonenergy Inputs: The Case of Middle Atlantic region," Journal of Regional Science, 3:411-420.

Wood, D.O. and R.B. Hirsch (1981), "Reconciling Econometric Studies of Factor Demand: Data and Measurement Issues," Energy Laboratory Working Paper, MIT-EL81-011WP, MIT. 
TABLE 1

MEAN VARIABLE VALUES

\begin{tabular}{|c|c|c|c|c|c|c|}
\hline Variable & $\begin{array}{l}\text { Micro } \\
\text { Weighted } \\
\text { (1) }\end{array}$ & $\begin{array}{l}\text { Full Sample } \\
\text { Data } \\
\text { Unweighted } \\
\text { (2) }\end{array}$ & $\begin{array}{c}\text { Agg. Data } \\
\text { 2-Digit } \\
\text { (3) }\end{array}$ & $\begin{array}{l}40 \text { 4-Dig } \\
\text { Micro Data } \\
\text { Weighted } \\
\text { (4) }\end{array}$ & $\begin{array}{l}\text { Industry } \\
\text { Aggreg } \\
\text { 4-Digit } \\
\text { 3-Digit } \\
\text { (5) }\end{array}$ & $\begin{array}{l}\text { Subsample } \\
\text { te Data }\end{array}$ \\
\hline $\mathrm{N}$ & 11520 & 11520 & 20 & 3637 & 40 & 27 \\
\hline $\begin{array}{l}\text { Output } \\
\text { (\$Million) }\end{array}$ & 19.61 & 116.42 & $131,699.26$ & 101.79 & $16,485.13$ & $27,592.23$ \\
\hline $\begin{array}{l}\text { Capital } \\
\text { (\$Million) }\end{array}$ & 7.33 & 50.40 & $50,809.54$ & 52.89 & $8,566.38$ & $14,480.59$ \\
\hline $\begin{array}{l}\text { Labor (Thousand } \\
\text { Hrs) }\end{array}$ & 253.40 & $1,063.29$ & $\begin{array}{c}1,773,166 \\
43\end{array}$ & 617.53 & $100,012.67$ & $174,740.09$ \\
\hline $\begin{array}{l}\text { Energy (Million } \\
\text { Btu) }\end{array}$ & 73.57 & 635.25 & $515,583.36$ & 969.71 & $157,048.89$ & $265,217.69$ \\
\hline $\begin{array}{l}\text { Materials } \\
\text { (\$Milion) }\end{array}$ & 9.67 & 59.84 & $68,373.13$ & 60.24 & $9,756.42$ & $17,198.89$ \\
\hline $\begin{array}{l}\text { Capital Cost } \\
\text { Share }\end{array}$ & 0.25 & 0.26 & 0.27 & 0.27 & 0.29 & 0.25 \\
\hline $\begin{array}{l}\text { Labor Cost } \\
\text { Share }\end{array}$ & 0.34 & 0.25 & 0.22 & 0.22 & 0.17 & 0.18 \\
\hline
\end{tabular}




\begin{tabular}{|c|c|c|c|c|c|c|}
\hline $\begin{array}{l}\text { Energy Cost } \\
\text { Share }\end{array}$ & 0.02 & 0.03 & 0.02 & 0.04 & 0.07 & 0.07 \\
\hline $\begin{array}{l}\text { Material Cost } \\
\text { Share }\end{array}$ & 0.39 & 0.46 & 0.49 & 0.46 & 0.48 & 0.50 \\
\hline Multi-Unit Firm & & 0.83 & & 0.74 & & \\
\hline $\begin{array}{l}\text { Total } \\
\text { Employment }\end{array}$ & 106 & 452 & 742,029 & 271 & 43,921 & 76,985 \\
\hline
\end{tabular}


TABLE 2

HYPOTHESIS TEST

\begin{tabular}{|c|c|c|c|}
\hline & $\begin{array}{l}\text { Cobb- } \\
\text { Douglas }\end{array}$ & $\mathrm{KLE} ; \mathrm{M}$ & CRTS \\
\hline $\begin{array}{l}\text { Restriction } \\
\text { s }\end{array}$ & $\beta_{i j}=\begin{array}{l}0 ; \\
j\end{array}$ & $\begin{array}{c}\sigma_{i M}=1 ; \text { for } \\
\text { alli }\end{array}$ & $\lambda=1.0$ \\
\hline $\begin{array}{l}\text { Critical } \\
\text { Value }\end{array}$ & $\begin{array}{c}\chi_{(99,10)}^{2}= \\
23.2\end{array}$ & $\chi_{(99,4)}^{\chi_{13.3}}=$ & $\chi_{(99,1)}^{2}=6.6$ \\
\hline $\begin{array}{l}\text { Test } \\
\text { Statistic }\end{array}$ & $41,982.2$ & $31,967.7$ & 13.2 \\
\hline
\end{tabular}

1 Likelihood Ratio Test: $\mathrm{L}=-2\left(\log\right.$ likelihood $_{r}-$ log likelihood ), where the restricted and unrestricted models are estimated on the weighted full sample 
TABLE 3

CAPITAL-ENERGY ELASTICITIES ${ }^{1}$

\begin{tabular}{|c|c|c|c|c|c|c|}
\hline \multirow{4}{*}{ Elasticity } & \multicolumn{3}{|c|}{ Full Sample } & \multicolumn{3}{|c|}{40 4-Digit Subsample } \\
\hline & \multicolumn{2}{|c|}{ Micro Data } & \multirow{3}{*}{$\begin{array}{l}\text { Agg } \\
\text { Data } \\
2- \\
\text { Digit } \\
\text { (3) }\end{array}$} & \multirow{3}{*}{$\begin{array}{l}\text { MicroDa } \\
\text { ta } \\
\text { Weighte } \\
\text { d } \\
\text { (4) }\end{array}$} & \multicolumn{2}{|c|}{ Aggregate Data } \\
\hline & $\begin{array}{c}\text { Weighte } \\
\text { d }\end{array}$ & Unwtd & & & $\begin{array}{r}4- \\
\text { Digit }\end{array}$ & $\begin{array}{r}3- \\
\text { Digit }\end{array}$ \\
\hline & $(1)$ & $(2)$ & & & (5) & (6) \\
\hline \multicolumn{7}{|l|}{$\begin{array}{l}\text { Price } \\
\text { Demand }\end{array}$} \\
\hline$\eta_{\mathrm{KK}}$ & -1.105 & $-1 \cdot 122$ & -0.668 & -1.060 & -1.742 & -1.987 \\
\hline$\eta_{\mathrm{EE}}$ & -3.574 & -2.802 & 14.529 & -2.922 & -2.079 & -2.858 \\
\hline$\eta_{\mathrm{KE}}$ & 0.015 & -0.040 & 1.145 & -0.014 & 0.048 & 0.250 \\
\hline$\eta_{\mathrm{EK}}$ & 0.208 & -0.301 & 14.778 & -0.087 & 0.200 & 0.953 \\
\hline \multicolumn{7}{|l|}{ Allen } \\
\hline$\sigma_{\mathrm{KK}}$ & -4.457 & -4.282 & -2.514 & -3.927 & -6.072 & -7.838 \\
\hline$\sigma_{\mathrm{EE}}$ & -195.482 & -80.744 & 705.176 & -66.124 & -30.388 & -43.047 \\
\hline$\sigma_{\mathrm{KE}}$ & 0.838 & -1.149 & 55.578 & -0.321 & 0.696 & 3.760 \\
\hline \multicolumn{7}{|l|}{ Morishima } \\
\hline$\sigma_{\mathrm{KE}}^{\mathrm{m}}$ & 3.589 & 2.762 & -13.384 & 2.908 & 2.126 & 3.107 \\
\hline$\sigma_{\mathrm{EK}}^{\mathrm{m}}$ & 1.313 & 0.821 & 15.447 & 0.973 & 1.942 & 2.940 \\
\hline \multicolumn{7}{|l|}{ Shadow } \\
\hline$\sigma_{\mathrm{KE}}^{\mathrm{s}}$ & 3.433 & 2.535 & -11.310 & 2.635 & 2.091 & 3.072 \\
\hline Capital Share & 0.248 & 0.262 & 0.266 & 0.270 & 0.287 & 0.253 \\
\hline Energy Share & 0.018 & 0.035 & 0.021 & 0.044 & 0.068 & 0.066 \\
\hline $\mathrm{N}$ & 11520 & 11520 & 20 & 3637 & 40 & 27 \\
\hline
\end{tabular}

${ }^{1}$ Based on actual cost shares. 


\section{Data Appendix}

The Manufacturing Energy Consumption Survey (MECS) collects energy production, consumption, and expenditure data from approximately 14,000 manufacturing plants. ${ }^{10}$ The MECS sample is a subset of the ASM, which is a representative sample of over 55,000 manufacturing plants drawn from the approximately 350,000 plants in the manufacturing universe. The 1991 MECS was designed to yield estimates on energy consumption for the entire manufacturing sector of the economy, as well as all the 20 twodigit major groups. In addition, the sampling design supports statistics for two three-digit industry groups, and 40 four-digit industries which meet one of the following criteria: i) energyintensive production in manufacturing; or ii) high-growth industries such as computers and medical instruments; or iii) industries with identifiable policy interest or conservation opportunities. The probability of selection is proportional to an energy measure of size. Thus, while all 3- and 4-digit manufacturing industries are not sampled sufficiently to generate aggregate statistics, the industries which would be most heavily

10 The basic unit of data collection for the MECS and ASM is the manufacturing establishment. An establishment is defined as a single physical location engaged in one of the categories of industrial activity in the Standard Industrial Classification (SIC) System. Manufacturing establishments are often referred to as plants, factories, or mills. This paper uses the term plants. 
impacted by changing energy conditions are well represented. Table A3 lists the SIC and industry breakdown of the MECS survey. We use two types of information from the MECS. For quantity of energy, we use the "quantity produced offsite and consumed as fuel" measure, as this is designed to be the equivalent to "cost of fuels" collected in the ASM. For energy prices, we use the "total expenditures, including delivery charges", divided by the "quantity purchased by and delivered to". Quantity of fuel is reported in a variety of measures, such as Btu, tons, cubic feet, gallons, or barrels, depending on the type of fuel. We convert the various physical units to millions of Btu in order to sum over types of fuel. Table A4 lists the reported units and conversion formulas, by type of fuel, used in this paper.

Data for all non energy inputs, output, plant location and primary industry are from the 1991 Annual Survey of Manufacturers (ASM). The ASM is conducted during non census years to provide information of economic characteristics for the manufacturing sector. ${ }^{11}$ Approximately 55,000 establishments from the universe of over 350,000 are surveyed. A new ASM panel is drawn every five years. The probability of being selected for the ASM is based on payroll and shipments size. Generally, only companies with more than 20 employees are selected for the ASM sampling frame. Large plants are surveyed every years with certainty.

11 A complete census is conducted in years ending in "2" or "7". 
The MECS and ASM data sets have two common plant identifiers which are used to link the two data sets: identification number and tab number. The identification number is a 10 digit number. For plants which are part of a multi-unit firm, the first six digits identifies the parent firm; the remaining four digits identifies the specific plant. For single-unit firms (plants), the entire ten digit number is unique to that plant. When a plant is sold, or its status from single to multi-unit firm ownership (or the reverse) changes, the identification number changes also. Linking the MECS with the ASM via the identification number fails in a small number of cases because of changes in ownership or firm status which are reflected in one data set, but not in the other, due to differences in the timing of processing and updating. When no match is found using the identification number, we rely on the six digit tabulation number, which for ASM plants, is assigned to a specific physical location. We are able to link over 99 percent of the MECS plant to the ASM.

The nature of the data collected in the ASM places some constraints on the measurement of production inputs and outputs. Economic information in the ASM is generally reported in thousands of dollars. Physical quantities of outputs and non labor inputs and prices are not collected. Output is defined as the total value of shipments, adjusted for changes in inventories 
of finished goods and work in progress. One advantage of using cross-section data is that we do not need individual plant prices or deflators.

As information on capital services, vintage, and intensity of use are unavailable, capital is measured by the sum of book value of capital equipment and structures, as information on physical capital is unavailable. Concerns about the obvious capital measurement problem are offset by Doms' (1996) and Dwyer's (1997) work with the Bureau's Longitudinal Research Database (LRD), which indicates book value is a reasonable proxy for physical capital. ${ }^{12}$ In determining the expenditure share for capital, we assume zero economic profits and calculate the residual of value of shipments minus labor, energy, and materials expenditures.

Ideally, labor input would be measured by total number of employee hours. While the ASM includes data on number of production and nonproduction employees and production and nonproduction salaries and wages, it collects only total production workers' hours. Rather than assume all employees work a 2,000 hour year, we assume that relative wages are proportional to marginal productivity and calculate production worker

12 Doms (1996) constructed capital based on the perpetual-inventory method and compares this series with the book value series. The correlation between the two series for his sample of plants is above 0.90. Thus, the reported book value should be a reasonable proxy for the physical capital stock. Dwyer (1997) found that measures of productivity constructed from different measures of capital are highly correlated and that their association with alternative measures of economic performance is approximately the same. 
equivalent hours for all employees. Total labor expenditures is equal to total salary and wages. Lastly, materials are measured by dollar expenditures for parts and materials and contract work. 
TABLE A1

SIC Coverage of MECS Survey

20 Food and Kindred Products

2011 Meat Packing Plants

2033 Canned Fruits and Vegetables

2037 Frozen Fruits and Vegetables

2046 Wet Corn Milling

2051 Bread, Cake, and Related Products

2063 Beet Sugars

2075 Soybean Oil Mills

2082 Malt Beverages

21 Tobacco Products

22 Textile Mill Products

23 Apparel and Other Textile Products

24 Lumber and Wood Products

25 Furniture and Fixtures

26 Paper and Allied Products

2611 Pulp Mills

2621 Paper Mills

2631 Paperboard Mills

27 Printing and Publishing

28 Chemicals and Allied Products

2812 Alkalies and Chlorine

2813 Industrial Gases

2819 Industrial Inorganic Chemicals, nec

2821 Plastics Materials and Resins

2822 Synthetic Rubber

2823 Cellulosic Manmade Fibers

2824 Organic Fibers, Noncellulosic

2865 Cyclic Crudes and Intermediates

2869 Industrial Organic Chemicals, nec

2873 Nitrogenous Fertilizers

2874 Phosphatic Fertilizers

29 Petroleum and Coal Products

2911 Petroleum Refining

30 Rubber and Misc. Plastics Products

3011 Tires and Inner Tubes

308 Miscellaneous Plastic Products, nec

31 Leather and Leather Products

32 Stone, Clay and Glass Products

3211 Flat Glass

3221 Glass Containers

3229 Pressed and Blown Glass, nec

3241 Cement, Hydraulic

3274 Lime

3296 Mineral Wool 
33 Primary Metal Industries

3312 Blast Furnaces and Steel Mills

3313 Electrometalurgical Products

3321 Gray and Doctile Iron Foundries

3331 Primary Copper

3334 Aluminum

3339 Primary Nonferrous Metals, nec

3353 Aluminum Sheet, Plate, and Foil

34 Fabricated Metal Products

35 Industrial Machinery and Equipment

357 Computer and Office Equipment

36 Electronic and Other Electric Equipment

37 Transportation Equipment

38 Instruments and Related Products

3841 Surgical and Medical Instruments

39 Misc. Manufacturing Industries 
TABLE A2

REGRESSION PARAMETER ESTIMATES

\begin{tabular}{|c|c|c|c|c|c|c|}
\hline \multirow{4}{*}{ Parameter } & \multicolumn{3}{|c|}{ Full Sample } & \multicolumn{3}{|c|}{40 4-Digit Subsample } \\
\hline & \multirow{3}{*}{$\begin{array}{c}\text { Weighted } \\
\text { (1) }\end{array}$} & \multirow{3}{*}{$\begin{array}{l}\text { Data } \\
\qquad \begin{array}{l}\text { Unwtd } \\
\text { (2) }\end{array}\end{array}$} & \multirow{3}{*}{$\begin{array}{c}\text { Agg Data } \\
\text { 2- } \\
\text { Digit } \\
\text { (3) }\end{array}$} & \multirow{3}{*}{$\begin{array}{l}\text { MicroDat } \\
\text { a } \\
\text { Weighted } \\
\text { (4) }\end{array}$} & \multirow{3}{*}{$\begin{array}{c}\text { Aggregate } \\
4- \\
\text { Digit } \\
\text { (5) }\end{array}$} & \multirow{3}{*}{$\begin{array}{l}\text { Data } \\
\qquad \begin{array}{r}3- \\
\text { Digit } \\
(6)\end{array}\end{array}$} \\
\hline & & & & & & \\
\hline & & & & & & \\
\hline$\dot{\alpha}_{\circ}$ & $\begin{array}{c}0.414 \\
(0.007)\end{array}$ & $\begin{array}{c}0.487 \\
(0.014)\end{array}$ & $\begin{array}{c}0.602 \\
(0.285)\end{array}$ & $\begin{array}{c}0.645 \\
(0.017)\end{array}$ & $\begin{array}{c}0.361 \\
(0.167)\end{array}$ & $\begin{array}{c}0.217 \\
(0.229)\end{array}$ \\
\hline$\dot{\alpha}_{\mathrm{K}}$ & $\begin{array}{c}0.198 \\
(0.001)\end{array}$ & $\begin{array}{c}0.213 \\
(0.002)\end{array}$ & $\begin{array}{c}0.209 \\
(0.108)\end{array}$ & $\begin{array}{c}0.235 \\
(0.002)\end{array}$ & $\begin{array}{c}0.301 \\
(0.066)\end{array}$ & $\begin{array}{c}0.272 \\
(0.094)\end{array}$ \\
\hline$\dot{\alpha}_{\mathrm{L}}$ & $\begin{array}{c}-0.094 \\
(0.001)\end{array}$ & $\begin{array}{c}-0.071 \\
(0.002)\end{array}$ & $\begin{array}{l}-0.046 \\
(0.087)\end{array}$ & $\begin{array}{c}-0.079 \\
(0.003)\end{array}$ & $\begin{array}{c}-0.083 \\
(0.038)\end{array}$ & $\begin{array}{c}-0.076 \\
(0.052)\end{array}$ \\
\hline$\dot{\alpha}_{\mathrm{E}}$ & $\begin{array}{c}0.023 \\
(0.0004)\end{array}$ & $\begin{array}{c}0.010 \\
(0.001)\end{array}$ & $\begin{array}{l}-0.020 \\
(0.020)\end{array}$ & $\begin{array}{l}-0.005 \\
(0.001)\end{array}$ & $\begin{array}{l}-0.038 \\
(0.037)\end{array}$ & $\begin{array}{c}-0.067 \\
(0.050)\end{array}$ \\
\hline$\dot{\alpha}_{\mathrm{M}}$ & $\begin{array}{c}0.876 \\
(0.001)\end{array}$ & $\begin{array}{c}0.841 \\
(0.001)\end{array}$ & $\begin{array}{c}0.848 \\
(0.060)\end{array}$ & $\begin{array}{c}0.839 \\
(0.002)\end{array}$ & $\begin{array}{c}0.825 \\
(0.029)\end{array}$ & $\begin{array}{c}0.881 \\
(0.032)\end{array}$ \\
\hline$\beta_{\mathrm{KK}}$ & $\begin{array}{c}0.047 \\
(0.0002)\end{array}$ & $\begin{array}{c}0.053 \\
(0.0002)\end{array}$ & $\begin{array}{c}0.075 \\
(0.033)\end{array}$ & $\begin{array}{c}0.052 \\
(0.0004)\end{array}$ & $\begin{array}{c}0.112 \\
(0.022)\end{array}$ & $\begin{array}{c}0.111 \\
(0.033)\end{array}$ \\
\hline$\beta_{\mathrm{LI}}$ & $\begin{array}{c}0.106 \\
(0.0003)\end{array}$ & $\begin{array}{l}0.094 \\
(0.0005)\end{array}$ & $\begin{array}{c}0.080 \\
(0.024)\end{array}$ & $\begin{array}{c}0.093 \\
(0.001)\end{array}$ & $\begin{array}{c}0.096 \\
(0.010)\end{array}$ & $\begin{array}{c}0.091 \\
(0.016)\end{array}$ \\
\hline$\beta_{\mathrm{EE}}$ & $\begin{array}{c}0.013 \\
(0.0001)\end{array}$ & $\begin{array}{c}0.021 \\
(0.0002)\end{array}$ & $\begin{array}{c}0.019 \\
(0.003)\end{array}$ & $\begin{array}{c}0.026 \\
(0.0002)\end{array}$ & $\begin{array}{c}0.034 \\
(0.010)\end{array}$ & $\begin{array}{c}0.039 \\
(0.014)\end{array}$ \\
\hline$\beta_{\mathrm{MM}}$ & $\begin{array}{c}0.169 \\
(0.0001)\end{array}$ & $\begin{array}{c}0.173 \\
(0.0004)\end{array}$ & $\begin{array}{c}0.215 \\
(0.020)\end{array}$ & $\begin{array}{c}0.170 \\
(0.001)\end{array}$ & $\begin{array}{c}0.197 \\
(0.008)\end{array}$ & $\begin{array}{c}0.201 \\
(0.013)\end{array}$ \\
\hline$\beta_{\mathrm{KL}}$ & $\begin{array}{c}0.007 \\
(0.0002)\end{array}$ & $\begin{array}{c}0.005 \\
(0.0003)\end{array}$ & $\begin{array}{c}0.020 \\
(0.027)\end{array}$ & $\begin{array}{l}0.002 \\
(0.0005)\end{array}$ & $\begin{array}{c}-0.012 \\
(0.011)\end{array}$ & $\begin{array}{c}-0.007 \\
(0.020)\end{array}$ \\
\hline$\beta_{\mathrm{KE}}$ & $\begin{array}{l}-0.001 \\
(0.0001)\end{array}$ & $\begin{array}{c}0.0005 \\
(0.0002)\end{array}$ & $\begin{array}{l}-0.002 \\
(0.007)\end{array}$ & $\begin{array}{l}-0.002 \\
(0.0003)\end{array}$ & $\begin{array}{l}-0.008 \\
(0.012)\end{array}$ & $\begin{array}{c}-0.018 \\
(0.017)\end{array}$ \\
\hline$\beta_{\mathrm{KM}}$ & $\begin{array}{l}-0.053 \\
(0.0001)\end{array}$ & $\begin{array}{l}-0.058 \\
(0.0003)\end{array}$ & $\begin{array}{l}-0.092 \\
(0.025)\end{array}$ & $\begin{array}{l}-0.052 \\
(0.0003)\end{array}$ & $\begin{array}{l}-0.092 \\
(0.010)\end{array}$ & $\begin{array}{c}-0.085 \\
(0.011)\end{array}$ \\
\hline$\beta_{\mathrm{IE}}$ & $\begin{array}{l}-0.004 \\
(0.0001)\end{array}$ & $\begin{array}{l}-0.003 \\
(0.0002)\end{array}$ & $\begin{array}{c}0.003 \\
(0.005)\end{array}$ & $\begin{array}{l}-0.0006 \\
(0.0004)\end{array}$ & $\begin{array}{c}-0.002 \\
(0.008)\end{array}$ & $\begin{array}{c}0.005 \\
(0.011)\end{array}$ \\
\hline$\beta_{\mathrm{IM}}$ & $\begin{array}{l}-0.109 \\
(0.0002)\end{array}$ & $\begin{array}{l}-0.096 \\
(0.0003)\end{array}$ & $\begin{array}{c}-0.103 \\
(0.008)\end{array}$ & $\begin{array}{l}-0.094 \\
(0.0005)\end{array}$ & $\begin{array}{l}-0.081 \\
(0.006)\end{array}$ & $\begin{array}{c}-0.089 \\
(0.005)\end{array}$ \\
\hline$\beta_{\mathrm{EM}}$ & $\begin{array}{l}-0.007 \\
(0.0001)\end{array}$ & $\begin{array}{l}-0.018 \\
(0.0002)\end{array}$ & $\begin{array}{l}-0.019 \\
(0.006)\end{array}$ & $\begin{array}{l}-0.024 \\
(0.0003)\end{array}$ & $\begin{array}{c}-0.024 \\
(0.006)\end{array}$ & $\begin{array}{l}-0.026 \\
(0.006)\end{array}$ \\
\hline
\end{tabular}




\begin{tabular}{lccc|ccc}
$\lambda$ & 1.004 & 0.993 & 0.991 & 0.991 & 1.004 & 1.010 \\
& $(0.001)$ & $(0.001)$ & $(0.018)$ & $(0.001)$ & $(0.010)$ & $(0.012)$ \\
$\begin{array}{l}\text { Log } \\
\text { Likelihood }\end{array}$ & 51660.3 & 49383.8 & 177.3 & 14492.9 & 281.7 & 181.9 \\
$\mathrm{~N}$ & 11,520 & 11,520 & 20 & 3,637 & 40 & 27 \\
\hline
\end{tabular}

Standard errors are given in parentheses. All regression include industry and region dummy variables, except 2-digit model. All regressions using unweighted micro data also include a multi-unit dummy variable. 
TABLE A3

ESTIMATED ELASTICITIES, KLEM MODELS ${ }^{1}$

\begin{tabular}{|c|c|c|c|c|c|c|}
\hline \multirow{4}{*}{ Elasticity } & \multicolumn{3}{|c|}{ Full Sample } & \multicolumn{3}{|c|}{40 4-Digit Subsample } \\
\hline & \multirow{3}{*}{$\begin{array}{l}\text { Weighted } \\
\text { (1) }\end{array}$} & \multirow{3}{*}{$\begin{array}{l}\text { Data } \\
\text { Unwtd } \\
\text { (2) }\end{array}$} & \multirow{3}{*}{$\begin{array}{l}\text { Agg Data } \\
2- \\
\text { Digit } \\
\text { (3) }\end{array}$} & \multirow{3}{*}{$\begin{array}{l}\text { MicroDat } \\
\text { a } \\
\text { Weighted } \\
\text { (4) }\end{array}$} & \multirow{3}{*}{$\begin{array}{l}\text { Aggregate } \\
4- \\
\text { Digit } \\
\text { (5) }\end{array}$} & \multirow{3}{*}{$\begin{array}{l}\text { Data } \\
\begin{array}{r}3- \\
\text { Digit } \\
(6)\end{array}\end{array}$} \\
\hline & & & & & & \\
\hline & & & & & & \\
\hline \multicolumn{7}{|l|}{ Price Demand } \\
\hline$\eta_{\mathrm{KK}}$ & -1.105 & $-1 \cdot 122$ & -0.668 & -1.060 & -1.742 & $-1 \cdot 987$ \\
\hline$\eta_{\mathrm{LL}}$ & $-1 \cdot 580$ & -1.929 & 0.888 & -2.164 & -3.426 & -3.097 \\
\hline$\eta_{\mathrm{EE}}$ & -3.584 & -2.802 & 14.523 & -2.922 & -2.079 & -2.858 \\
\hline$\eta_{\mathrm{MM}}$ & -2.135 & -2.053 & 4.970 & -2.152 & -2.815 & -2.727 \\
\hline$\eta_{\mathrm{KL}}$ & 0.011 & -0.045 & 1.064 & -0.010 & -0.188 & -0.161 \\
\hline$\eta_{\mathrm{KE}}$ & 0.015 & -0.040 & 1.145 & -0.014 & 0.048 & 0.250 \\
\hline$\eta_{\mathrm{KM}}$ & 1.079 & 1.207 & -1.541 & 1.084 & 1.882 & 1.899 \\
\hline$\eta_{\mathrm{LK}}$ & 0.008 & -0.049 & 1.276 & -0.012 & -0.321 & -0.230 \\
\hline$\eta_{\mathrm{LE}}$ & 0.029 & -0.065 & 2.145 & -0.185 & -0.134 & -0.481 \\
\hline$\eta_{\mathrm{LM}}$ & 1.543 & 2.042 & $-4 \cdot 310$ & 2.362 & 3.881 & 3.808 \\
\hline$\eta_{E K}$ & 0.208 & -0.301 & 14.778 & -0.087 & 0.200 & 0.953 \\
\hline$\eta_{E L}$ & 0.538 & -0.456 & 23.082 & -0.938 & -0.329 & -1.287 \\
\hline$\eta_{\mathrm{EM}}$ & 2.828 & 3.560 & -52.389 & 3.947 & 2.208 & 3.191 \\
\hline$\eta_{\mathrm{MK}}$ & 0.678 & 0.691 & -0.833 & 0.633 & 1.132 & 0.958 \\
\hline$\eta_{\mathrm{ML}}$ & 1.326 & 1.093 & $-1 \cdot 943$ & 1.142 & 1.366 & 1.347 \\
\hline$\eta_{\mathrm{ME}}$ & 0.131 & 0.270 & -2.195 & 0.377 & 0.317 & 0.422 \\
\hline \multicolumn{7}{|l|}{ Allen } \\
\hline$\sigma_{\mathrm{KK}}$ & -4.457 & -4.282 & -2.514 & -3.927 & -6.072 & -7.838 \\
\hline$\sigma_{\mathrm{LL}}$ & -4.660 & -7.869 & -4.007 & -9.678 & -20.418 & -17.427 \\
\hline$\sigma_{\mathrm{EE}}$ & -195.482 & -80.744 & 705.176 & -66.124 & -30.388 & -43.047 \\
\hline$\sigma_{\mathrm{MM}}$ & -5.412 & -4.481 & 10.106 & -4.656 & -5.902 & -5.428 \\
\hline
\end{tabular}




\begin{tabular}{|c|c|c|c|c|c|c|}
\hline$\sigma_{\mathrm{KL}}$ & 0.034 & -0.185 & 4.800 & -0.044 & -1.120 & -0.909 \\
\hline$\sigma_{\mathrm{KE}}$ & 0.838 & -1.149 & 55.578 & -0.321 & 0.696 & 3.760 \\
\hline$\sigma_{\mathrm{KM}}$ & 2.733 & 2.635 & -3.133 & 2.345 & 3.947 & 3.779 \\
\hline$\sigma_{\mathrm{LE}}$ & 1.587 & -1.862 & 104.121 & -4.195 & -1.961 & -7.240 \\
\hline$\sigma_{\mathrm{LE}}$ & 3.911 & 4.458 & -8.763 & 5.108 & 8.139 & 7.580 \\
\hline$\sigma_{\mathrm{EM}}$ & 7.167 & 7.771 & -106.522 & 8.537 & 4.629 & 6.352 \\
\hline \multicolumn{7}{|c|}{ Morishima } \\
\hline$\sigma_{\mathrm{KL}}^{\mathrm{m}}$ & 1.592 & 1.883 & 0.176 & 2.154 & 3.238 & 2.936 \\
\hline$\sigma_{\mathrm{KE}}^{\mathrm{m}}$ & 3.589 & 2.762 & -13.384 & 2.908 & 2.126 & 3.107 \\
\hline$\sigma_{\mathrm{KM}}^{\mathrm{m}}$ & 3.214 & 3.260 & -6.511 & 3.237 & 4.697 & 4.626 \\
\hline$\sigma_{\mathrm{LK}}^{\mathrm{m}}$ & 1.114 & 1.073 & 1.945 & 1.048 & 1.421 & 1.757 \\
\hline$\sigma_{\mathrm{LE}}^{\mathrm{m}}$ & 3.603 & 2.738 & -12.383 & 2.736 & 1.945 & 2.377 \\
\hline$\sigma_{\mathrm{LM}}^{\mathrm{m}}$ & 3.678 & 4.095 & -9.280 & 4.514 & 6.696 & 6.535 \\
\hline$\sigma_{\mathrm{EK}}^{\mathrm{m}}$ & 1.313 & 0.231 & 15.447 & 0.973 & 1.942 & 2.940 \\
\hline$\sigma_{\mathrm{EL}}^{\mathrm{m}}$ & 2.119 & 1.472 & 22.194 & 1.226 & 3.097 & 1.811 \\
\hline$\sigma_{\mathrm{EM}}^{\mathrm{m}}$ & 4.963 & 5.613 & -57.359 & 6.099 & 5.022 & 5.918 \\
\hline$\sigma_{\mathrm{MK}}^{\mathrm{m}}$ & 1.783 & 1.813 & -0.165 & 1.693 & 2.874 & 2.945 \\
\hline$\sigma_{\mathrm{ML}}^{\mathrm{m}}$ & 2.907 & 3.022 & -2.831 & 3.307 & 4.792 & 4.445 \\
\hline$\sigma_{\mathrm{ME}}^{\mathrm{m}}$ & 3.705 & 3.072 & -16.723 & 3.299 & 2.395 & 3.279 \\
\hline \multicolumn{7}{|c|}{ Shadow } \\
\hline$\sigma_{\mathrm{KL}}^{\mathrm{s}}$ & 1.316 & 1.492 & 0.982 & 1.653 & 2.567 & 2.450 \\
\hline$\sigma_{\mathrm{KE}}^{\mathrm{s}}$ & 3.433 & 2.535 & $-11 \cdot 310$ & 2.635 & 2.091 & 3.072 \\
\hline$\sigma_{\mathrm{KM}}^{\mathrm{s}}$ & 2.335 & 2.234 & -2.392 & 2.262 & 3.559 & 3.508 \\
\hline$\sigma_{\mathrm{LE}}^{\mathrm{s}}$ & 3.527 & 2.581 & -9.443 & 2.487 & 2.278 & 2.223 \\
\hline$\sigma_{\mathrm{LM}}^{\mathrm{s}}$ & 3.263 & 3.396 & -4.835 & 3.700 & 5.287 & 4.991 \\
\hline$\sigma_{\mathrm{EM}}^{\mathrm{s}}$ & 3.761 & 3.251 & -18.357 & 3.543 & 2.725 & 3.587 \\
\hline $\mathrm{N}$ & 11,520 & 11,520 & 20 & 3,637 & 40 & 27 \\
\hline
\end{tabular}

1 Based on actual shares. 
TABLE A4

MECS Reporting Units of Quantity and

BTU Conversion, by Fuel Type

\begin{tabular}{|c|c|c|}
\hline Type of Fuel & MECS Reporting Units & $\begin{array}{l}\text { Conversion to Million } \\
\text { Btu }\end{array}$ \\
\hline \multicolumn{3}{|l|}{ Noncombustible } \\
\hline Electricity & $\begin{array}{l}\text { Thousand kilowatt } \\
\text { hours }\end{array}$ & $\times 3.412$ \\
\hline Steam & Million Btu & \\
\hline $\begin{array}{l}\text { Industrial Hot } \\
\text { Water }\end{array}$ & Million Btu & \\
\hline \multicolumn{3}{|l|}{ Combustible } \\
\hline \multicolumn{3}{|l|}{ Solids } \\
\hline Anthracite & Short Tons & x 27.751 \\
\hline $\begin{array}{l}\text { Bituminous \& } \\
\text { Subbituminous } \\
\text { Coal }\end{array}$ & Short Tons & $\times 22.407$ \\
\hline Lignite & Short Tons & $\times 22.407$ \\
\hline Breeze & Short Tons & $\times 24.800$ \\
\hline Coal coke & Short Tons & $x \quad 24.800$ \\
\hline $\begin{array}{l}\text { Fluid Catalytic } \\
\text { Cracking } \\
\text { Unit Coke }\end{array}$ & Barrels & $\times 6.024$ \\
\hline $\begin{array}{l}\text { Unrefined or } \\
\text { Green } \\
\text { Petroleum Coke }\end{array}$ & Barrels & $\times 6.024$ \\
\hline $\begin{array}{l}\text { Calcined } \\
\text { Petroleum } \\
\text { Coke }\end{array}$ & Barrels & $\times 6.024$ \\
\hline Roundwood & Million Btu & \\
\hline $\begin{array}{l}\text { Wood Chips, Bark, } \\
\text { Waste }\end{array}$ & Million Btu & \\
\hline Biomass & Million Btu & \\
\hline $\begin{array}{c}\text { Waste } \\
\text { Materials/Scrape }\end{array}$ & Million Btu & \\
\hline
\end{tabular}


Other Solids Milion Btu

\begin{tabular}{|c|c|c|}
\hline Natural Gas & Thousand Cubic Feet & x 1.031 \\
\hline Acetylene & Million Btu & \\
\hline Blast Furnace Gas & Million Btu & \\
\hline Coke Oven Gas & Million Btu & \\
\hline Hydrogen & Million Btu & \\
\hline $\begin{array}{l}\text { Waste \& Byproduct } \\
\text { Gases }\end{array}$ & Million Btu & \\
\hline Other Gases & Million Btu & \\
\hline Liquids & & \\
\hline Butane & Gallons & $/ 42 \times 3.821$ \\
\hline Ethane & Gallons & $/ 42 \times 3.821$ \\
\hline Propane & Gallons & $/ 42 \times 3.821$ \\
\hline $\begin{array}{l}\text { Other LPG \& NGL } \\
\text { Liquids }\end{array}$ & Gallons & $/ 42 \times 3.821$ \\
\hline Diesel Fuel & Barrels & $\times 5.825$ \\
\hline Oil Distillate Fuel & Barrels & $\times 5.825$ \\
\hline Kerosene & Barrels & $x \quad 5.670$ \\
\hline Motor Gasoline & Gallons & $/ 42 \times 2.253$ \\
\hline $\begin{array}{l}\text { Pulping or Black } \\
\text { Liquor }\end{array}$ & Million Btu & \\
\hline Residual Fuel Oil & Million Btu & \\
\hline Waste Oils \& Tars & Million Btu & \\
\hline Other Liquids & Million Btu & \\
\hline
\end{tabular}


CES Discussion Papers are available in two subscription formats: (INTERNET and Yearly Series single paper copy.) Ordering information is found on the attached CES Discussion Paper Subscription \& Request Form. In addition, papers are sold individually for the amount of $\$ 5.00$ per paper.

97-4 "Capital-Energy Substitution Revisitied: New Evidence from Micro Data" by Sang V. Nguyen and Mary L. Streitwieser, 4/97. (55 pages)

97-3 "Productivity Races II: The Issue of Capital Measurement" by Douglas Dwyer, 3/97. (29 pages)

97-2 "Productivity Races I: Are some Productivity Measures Better than Others?" by Douglas Dwyer, 2/97.(47 pages)

97-1 "Survival Patterns Among Newcomers to Franchising" by Timothy Bates, 1/97. (45 pages)

96-14 "Evidence on the Link Between Firm-Level and Aggregate Inventory Behavior" by Scott Shuh, 12/96. (58 pages)

96-13 "Business Failure in the 1992 Establishment Universe Sources of Population Heterogeneity" by Alfred Nucci, 12/96. (25 pages)

96-12 "Efficiency of Bankrupt Firms and Industry Conditions: Theory and Evidence" by Vojislav Maksimovic and Gordon Phillips, 12/96. ( 48 pages)

96-11 "Whittling Away at Productivity Dispersion Further Notes: Persistent Dispersion or Measurement Error?" by Douglas Dwyer, 11/96. (20 pages)

96-10 "Firm Performance and Evolution: Empirical Regularities in the U.S. Microdata" by J. Bradford Jensen and Robert H. McGuckin, 10/96. (38 pages)

96-9 "Financing Small Business Creation: The Case of Chinese and Korean Immigrant Entrepreneurs" by Timothy Bates, 9/96. (40 pages)

96-8 "Measuring the Impact of the Manufacturing Extension Partnership" by Ronald S. Jarmin, 9/96. (39 pages)

96-7 "Technology and Jobs: Secular Changes and Cyclical Dynamics" by Timothy Dunne, John Haltiwanger and Kenneth R. Troske, 9/96. (94 pages)

96-6 "Interfirm Segregation and the Black/White Wage Gap" by William J. Carrington and Kenneth R. Troske, 8/96. (62 pages)

96-5 "Learning by Doing and Plant Characteristics" by Ronald S. Jarmin, $8 / 96$. ( 40 pages)

96-4 "Sex Segregation in U.S. Manufacturing" by William J. Carrington and Kenneth R. Troske, 6/96. (50 pages). 
96-3 "Are Fixed Effects Fixed?" by Douglas Dwyer, 5/96. (55 pages)

96-2 "The Effect of Technology Use on Productivity Growth", by Robert H. McGuckin, Mary L. Streitweiser, and Mark E. Doms 8/96. (45 pages)

96-1 "Evaluation and Use of the Pollution Abatement Costs and Expenditures Survey Micro Data", by Mary L. Streitweiser 3/96. (78 pages)

95-14 "Innovation and Regulation in the Pesticide Industry", by Michael Ollinger and Jorge Fernandez-Cornejo, 12/95. (53 pages)

95-13 "Exploring the Role of Acquisition in the Performance of Firms: Is the "Firm" the Right Unit of Analysis?", by Robert H. McGuckin and Sang V. Nguyen, 11/95. (29 pages)

95-12 "The Missing Link: Technology, Productivity, and Investment", by Laura Power, 10/95. (39 pages)

95-11 "Counting the Self-Employed From Two Perspectives: Household vs. Business Sample Data", by Richard J. Boden and Alfred R. Nucci, 9/95. (22 pages)

95-10 "The Worker-Establishment Characteristics Database", by Kenneth R. Troske, 6/95. Forthcoming in Labor Statistics Measurement Issue, eds. John Haltiwanger, Marilyn Manser, and Robert Topel. Chicago: NBER. ( 45 pages)

95-9 "Retail Inventories, Internal Finance, and Aggregate Fluctuations: Evidence from Firm-Level Panel Data", by Egon Zakrajsek, 5/95. ( 40 pages)

95-8 "The Impact of Ownership Change on Employment, Wages, and Labor Productivity in U.S. Manufacturing 1977-87", by Robert H. McGuckin, Sang V. Nguyen, and Arnold P. Reznek, 4/95. Forthcoming in Labor Statistics Measurement Issue, eds. John Haltiwanger, Marilyn Manser, and Robert Topel. Chicago: NBER. (57 pages).

95-7 "Using Matched Client and Census Data to Evaluate the Performance of the Manufacturing Extension Partnership", by Ron S. Jarmin, $4 / 95$. ( 40 pages)

95-6 "Technology Locks, Creative Destruction and Non-Convergence in Productivity Levels", By Douglas Dwyer, 4/95. (59 pages)

95-5 "Whittling Away at Productivity Dispersion", by Douglas Dwyer, $3 / 95$. (37 pages)

95-4 "Capital Structure and Product Market Behavior: An Examination of Plant Exit and Investment Decisions", by Dan Kovenock and Gordon M. Phillips, 3/95. (56 pages)

95-3 "Capital Structure and Product Marker Rivalry: How Do We Reconcile Theory and Evidence?", by Dan Kovenock and Gordon Phillips, 2/95. (15 pages)

95-2 "Small Businesses Do Appear to Benefit from State/Local Government Economic Development Assistance", by Timothy Bates, 2/95. (35 pages) 
95-1 "Preferential Procurement Programs do not Necessarily Help Minority-

Owned Businesses", by Timothy Bates \& Darrell Williams, 1/95. (36 pages)

CES DISCUSSION PAPER LISTINGS DATED BACK TO 1988 ARE AVAILABLE UPON REQUEST. CES Discussion Paper Subscription and Request Form

G Yes, I'd like to subscribe to the following:

G Regular announcements of the CES Discussion Paper Series on the INTERNET, free of charge.

G Yearly subscription to the CES Discussion Paper Series in single paper copy for a fee of $\$ 75.00$ per year.

The CES Annual Report is available (free of charge). $G$ Please add my name to your mailing list.

$G$ No, I don't want to subscribe at this time but, I would like to order the following CES Discussion Paper(s):

CES\# CES\# CES\# Total \$

NAME

ADDRESS

Phone ( )

$\operatorname{FAX} \quad(\quad)$

INTERNET ADDRESS

$G$ Check here if this is an change of address.

METHOD OF PAYMENT: Make payable to: Commerce, Census

G Check G Money order G Mastercard G Visa

Card Number

Expiration Date:

Month Year

Amount enclosed: \$

Please send order form and payment to:

The Center for Economic Studies

4700 Silver Hill Road, Stop 6300 
Washington, D.C. 20233-6300

Attn: Tracy C. Crosby 